\title{
Expression of excess receptors and negative feedback control of signal pathways are required for rapid activation and prompt cessation of signal transduction
}

\author{
Hiroshi Kobayashi*1, Ryuzo Azuma2,3 and Takuo Yasunaga 2,3
}

\begin{abstract}
Address: ${ }^{1}$ Department of Biochemistry, Graduate School of Pharmaceutical Sciences, Chiba University, 1-8-1, Inohana, Chuo-ku, Chiba 260-8675, Japan, ${ }^{2}$ Department of Bioscience and Bioinformatics, Graduate School of Computer Science and Systems Engineering, Kyushu Institute of Technology, 680-4 Kawazu, Iizuka, Fukuoka 820-0067, Japan and 3Japan Science and Technology Agency, Core Research for Evolutional Science and Technology (JST/CREST), Sanbancho Bldg, 5, Sanbancho, Chiyoda-ku, Tokyo 102-0075, Japan

Email: Hiroshi Kobayashi* - hiroshi@p.chiba-u.ac.jp; Ryuzo Azuma - azuma@bio.kyutech.ac.jp; Takuo Yasunaga - yasunaga@bio.kyutech.ac.jp

* Corresponding author
\end{abstract}

Published: 3 March 2009

Cell Communication and Signaling 2009, 7:3 doi:10.1186/1478-8IIX-7-3

This article is available from: http://www.biosignaling.com/content/7/I/3

(C) 2009 Kobayashi et al; licensee BioMed Central Ltd.

This is an Open Access article distributed under the terms of the Creative Commons Attribution License (http://creativecommons.org/licenses/by/2.0), which permits unrestricted use, distribution, and reproduction in any medium, provided the original work is properly cited.
Received: 29 December 2008

Accepted: 3 March 2009

\begin{abstract}
Background: Cellular signal transduction is initiated by the binding of extracellular ligands to membrane receptors. Receptors are often expressed in excess, and cells are activated when a small number of receptors bind ligands. Intracellular signal proteins are activated at a high level soon after ligand binding, and the activation level decreases in a negative feedback manner without ligand clearance. Why are excess receptors required? What is the physiological significance of the negative feedback regulation?

Results: To answer these questions, we developed a Monte Carlo simulation program to kinetically analyze signal pathways using the model in which ligands are bound to receptors and then membrane complexes with other membrane proteins are formed. Our simulation results showed that excess receptors are not required for cell activation when the dissociation constant $(K d)$ of the ligand-receptor complex is $10^{-10} \mathrm{M}$ or less. However, such low $\mathrm{Kd}$ values cause delayed signal shutdown after ligand clearance from the extracellular space. In contrast, when the $\mathrm{Kd}$ was $10^{-8} \mathrm{M}$ and the ligand level was less than I $\mu \mathrm{M}$, excess receptors were required for prompt signal propagation and rapid signal cessation after ligand clearance. An initial increase in active cytosolic signal proteins to a high level is required for rapid activation of cellular signal pathways, and a low level of active signal proteins is essential for the rapid shutdown of signal pathways after ligand clearance.
\end{abstract}

Conclusion: The present kinetic analysis revealed that excess receptors and negative feedback regulation promote activation and cessation of signal transduction with a low amount of extracellular ligand.

\section{Background}

Cellular signal transduction is mediated by a complex system involving many proteins. Experimental studies have unraveled several transduction pathways and the roles of many proteins, but many questions remain unanswered. It has been shown that successful cellular activation only requires ligand binding by a small fraction of the available receptors. For example, HeLa cells have been shown to 
express approximately 50,000 EGF receptors per cell, but binding of only 300 EGF molecules to the cell surface is sufficient to activate $50 \%$ of cells [1]. Why do cells express an excess number of receptors?

It is generally accepted that the binding of extracellular ligands to membrane receptors initiates the phosphorylation of signal proteins in a stepwise manner. Many studies have suggested that the majority of signal proteins are phosphorylated immediately after the binding of a ligand to its receptor, after which the level of signal protein decreases [2-7]. To explain this change, it has been hypothesized that the inactivation of signal proteins is regulated in a negative feedback manner by the active form of the signal protein of a late reaction step, thereby decreasing the levels of active proteins [8-10]. However, it remains unclear why this kind of negative feedback regulation is required.

Kinetic analysis is a useful way to analyze these questions. Simple reactions that are mediated by a single enzyme have been analyzed using classical enzyme kinetics, but this method is hard to apply to the kinetic analysis of signal pathways because of their complexity. Recently, an elegant way to facilitate quantification has been developed with the aid of computers. Two types of computer simulation techniques are now available for theoretical studies of biological phenomena: numerical integration of differential equations and Monte Carlo simulation. The former method can be used to evaluate average behavior involving a large number of molecules and stochastic variation. In contrast, the latter can simulate both population behavior and single molecule dynamics. Monte Carlo simulation can also address time-dependent fluctuations involving noise as well as cell-to-cell population heterogeneity.

Receptor-ligand complex formation has been simulated using Monte Carlo techniques [11-13], but these previous analyses have not answered the above questions. Our group developed Monte Carlo simulation programs using a conventional personal computer with Windows XP or 2000 operating systems to examine the kinetic significance of the clustering of membrane receptors and their associate proteins and found that the pre-clustering of such proteins promotes cellular signaling [14]. In the present study, our previous technique was applied to clarify why cells have an excess amount of receptors and why negative feedback regulation is required. We used the following model in the present simulation. Extracellular ligands are bound to receptors and then membrane complexes with other membrane proteins are formed. In this model, pre-clustering of membrane proteins is required for efficient cell activation as shown previously
[14]. The complex activates the first cytosolic signal protein and other signal proteins are activated step by step.

\section{Methods}

In the present study, we assumed a simplified model in which the cell surface is represented as a 2-dimensional plane between 3-dimensional extracellular and cytosolic spaces (Figure 1-I). The cell surface and the extracellular space were divided into subspaces. Real-type pseudo uniform random numbers $(\mathrm{N})$ with the range $0 \leq \mathrm{N}<1$ were generated as reported previously [15]. Each molecule was assumed to undergo random motion with a diffusion rate (v) that has a pseudo-normal probability distribution from 0 to 100 . $v$ was generated as described in Table 1, and the resulting distribution is shown in Figure 1-II. Each molecule has $v$ and its direction of movement (positive or negative direction on each axis), and molecules move into their neighboring subspace when $\tau<v$, where $\tau$ is a
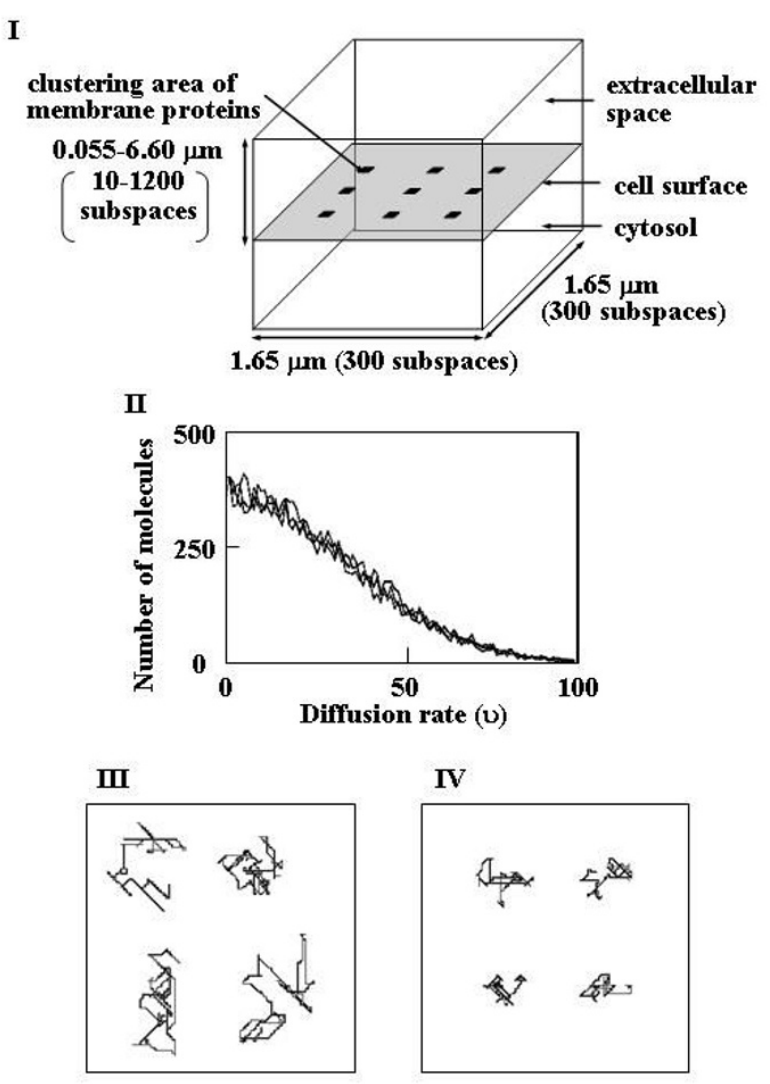

\section{Figure I}

Cell model for simulation, molecular diffusion rates, and receptor movement. $(A)$ The cell model used for simulation. See text for details. (B) Distribution of diffusion rates ( $v$ ). For details, see text. (C,D) Movement of $R$ was plotted for $1 \times 10^{4}$ steps at intervals of 10 steps. The diffusion rates of $R$ used were $v(C)$ and $0.1 v(D)$. The numbers of subspaces were $600 \times 600 \times I$ (C) and $300 \times 300 \times I(D)$. 
Table I: A list of integral random numbers

\begin{tabular}{lll}
\hline Used for & Range & Equations \\
\hline Diffusion rate $(\mathrm{U})$ & $0-99$ & Absolute value of $(\mathrm{S} / 6-200)$, where $\mathrm{S}=\sum_{\mathrm{i}=1}^{12}\left(\mathrm{~N}_{\mathrm{i}} \times 200\right)(1)$ \\
Selection of moving step $(\tau)$ & $0-99$ & $\mathrm{~N} \times 100(2)$
\end{tabular}

A pseudo uniform random number $(\mathrm{N})$ from 0 to $\left(\mathrm{I}-\mathrm{I} \times 10^{-15}\right)$ was generated as described in the Methods.

(I) $S$ is the integer of the obtained value, and $S$ values of 100 or less were used.

(2) The integer of the obtained value was used.

pseudo uniform random number $(0 \leq \tau<100)$ obtained as described in Table $1 . v$ was defined as the diffusion rate of the extracellular ligand and cytosolic proteins, and $0.1 \mathrm{v}$ was used for the rate of membrane proteins and their complexes with the ligand. When $v=0$, the molecules remained in the same subspace. The diffusion rates and directions were updated for $1 \%$ of all molecules at each step, and this sample population was selected randomly. The trajectories of the receptors are shown in Figure 1-III and 1-IV. We assumed periodic boundary conditions; i.e., a molecule moved to the opposite side when it reached the boundary of its simulation box, except that when it reached the cell surface or its opposite boundary, it was reflected in the mirror direction.

Nine clustering areas were assumed for membrane components, as illustrated in Figure 1-I, and each area consisted of $3 \times 3$ subspaces with energy barriers at each boundary. The energy required to escape from the clustering area was defined as 23.7 kilojoules $\cdot$ mole $^{-1}$. This means that the probability of escaping from the clustering area beyond its boundary was $0.01 \%$ at a temperature of $310 \mathrm{~K}$. To avoid bias, the candidate for each trial was selected randomly. The molecules that were not selected were reflected in the mirror-direction at the boundaries of the clustering areas. Under these conditions, $99.2 \%$ of membrane components were clustered in the 9 clustering areas. When the escaping possibility was set to $0.1 \%, 92 \%$ of membrane components were clustered.

All molecules were initially distributed into randomly selected subspaces of their own compartments with equal probability, and $99.2 \%$ of the membrane proteins clustered within $1.2 \times 10^{6}$ steps under standard conditions.

The LR and LRA complexes were assumed to form in the membranes by the following reactions:

$$
\mathrm{L}+\mathrm{R} \leftrightarrow \mathrm{LR}, \mathrm{LR}+\mathrm{A} \leftrightarrow \mathrm{LRA}
$$

where $\mathrm{L}, \mathrm{R}$, and $\mathrm{A}$ are an extracellular ligand, a membrane receptor, and a membrane protein such as an adaptor or a linker, respectively. LR and LRA are binary and ternary complexes, respectively. Two molecules of different spe- cies may bind to each other when they occupy the same subspace. The binding probability and the dissociation probability of the complexes were defined as described previously [14].

LR was rapidly converted to LRA, since R and A clustered before $\mathrm{L}$ was added. Therefore, the rate constant of LRA formation $(k)$ was calculated as follows:

$$
\mathrm{d}[\mathrm{LRA}] / \mathrm{dt}=k[\mathrm{~L}][\mathrm{R}]
$$

A cytosolic signal pathway was postulated as follows. The first cytosolic signal protein (B) is activated by the following reaction:

$$
\mathrm{LRA}+\mathrm{B} \rightarrow \mathrm{LRA} \cdot \mathrm{B} \rightarrow \mathrm{LRA} \cdot \mathrm{B}^{*} \rightarrow \mathrm{LRA}+\mathrm{B}^{*},
$$

where $\mathrm{B}^{*}$ is the activated form of $\mathrm{B} . \mathrm{B}^{*}$ is inactivated by

$$
\mathrm{I}_{\mathrm{B}}^{*}+\mathrm{B}^{*} \rightarrow \mathrm{I}_{\mathrm{B}}^{*} \cdot \mathrm{B}^{*} \rightarrow \mathrm{I}_{\mathrm{B}}^{*} \cdot \mathrm{B} \rightarrow \mathrm{I}_{\mathrm{B}}^{*}+\mathrm{B}
$$

where $I_{B}{ }^{*}$ is the active form of enzyme $I_{B}$, which inactivates $\mathrm{B}^{*}$.

The second signal protein $(\mathrm{C})$ is activated by the following reaction:

$$
\mathrm{B}^{*}+\mathrm{C} \rightarrow \mathrm{B}^{*} \cdot \mathrm{C} \rightarrow \mathrm{B}^{*} \cdot \mathrm{C}^{*} \rightarrow \mathrm{B}^{*}+\mathrm{C}^{*}
$$

where $\mathrm{C}^{*}$ is the activated $\mathrm{C}$, and $\mathrm{C}^{*}$ is inactivated by

$$
\mathrm{I}_{\mathrm{C}}^{*}+\mathrm{C}^{*} \rightarrow \mathrm{I}_{\mathrm{C}}^{*} \cdot \mathrm{C}^{*} \rightarrow \mathrm{I}_{\mathrm{C}}^{*} \cdot \mathrm{C} \rightarrow \mathrm{I}_{\mathrm{C}}^{*}+\mathrm{C},
$$

where $\mathrm{I}_{\mathrm{C}}{ }^{*}$ is the activated form of the enzyme that inactivates $C^{*}$. We considered a signal pathway consisting of 5 signal proteins, $\mathrm{B}$ to $\mathrm{F}$, all of which were subjected to the same reaction as described above. The probability of each reaction was defined based on its activation energy as described previously [14].

The source code of our simulation program was implemented with Visual Studio C++.net (Microsoft Co.), and the program was run on a personal computer with Windows XP or 2000 (Microsoft Co.). 


\section{Results}

\section{Validation of our simulation methods}

In the previous simulation [14], the volume of a single subspace was defined as $1.728\left(1.20^{3}\right) \mathrm{nm}^{3}$, but this volume is smaller than the size of a large number of protein complexes. Therefore, in this study we defined that a single subspace was a cubic box with a volume of 166.1 $\left(5.497^{3}\right) \mathrm{nm}^{3}$, as described previously [16]. In this model, one molecule per subspace corresponds to a concentration of $10 \mathrm{mM}$. Each calculation step was assumed to take 0.02 milliseconds.

To validate our simulation procedure, the dissociation constant $(\mathrm{Kd})$ of the following reaction in the cytosolic space was evaluated.

$$
\mathrm{A}+\mathrm{B} \leftrightarrow \mathrm{AB}
$$

In the equilibrium state, the following equation holds:

$$
\mathrm{P}_{1} \times \mathrm{N}_{\mathrm{A}} \times \mathrm{N}_{\mathrm{B}} / \mathrm{N}_{\mathrm{S}}=\mathrm{P}_{2} \times \mathrm{N}_{\mathrm{AB}}
$$

where $\mathrm{N}_{\mathrm{A}}, \mathrm{N}_{\mathrm{B}}$, and $\mathrm{N}_{\mathrm{AB}}$ are the numbers of molecules $\mathrm{A}, \mathrm{B}$, and $A B$, respectively. $P_{1}$ and $P_{2}$ are the binding and dissociation probabilities and are defined as $\exp \left(-\Delta \mathrm{E}_{1} / \mathrm{RT}\right)$ and $\exp \left(-\Delta \mathrm{E}_{2} / \mathrm{RT}\right)$, respectively. Where $\mathrm{E}, \mathrm{R}$, and $\mathrm{T}$ are the activation energy, gas constant, and absolute temperature, respectively. $N_{S}$ is the number of subspaces in the cytosolic space. Since one molecule per subspace corresponds to a concentration of $10 \mathrm{mM}$ as described above, the molarities of $A\left(M_{A}\right), B\left(M_{B}\right)$, and $A B\left(M_{A B}\right)$ are given by $\mathrm{N}_{\mathrm{A}} /\left(100 \times \mathrm{N}_{\mathrm{S}}\right), \mathrm{N}_{\mathrm{B}} /\left(100 \times \mathrm{N}_{\mathrm{S}}\right)$, and $\mathrm{N}_{\mathrm{AB}} /\left(100 \times \mathrm{N}_{\mathrm{S}}\right)$, respectively. By defining the dissociation constant $(\mathrm{Kd})$ as $\left(M_{A} \times M_{B}\right) / M_{A B}$, we get $K d=P_{2} /\left(P_{1} \times 100\right)$.

The numbers of A and $\mathrm{B}$ were both set to 600, and the cytosolic space contained $300 \times 300 \times 100$ subspaces. $\mathrm{P}_{1}$ was set to 0.670 . As shown in Table 2 , the simulated $\mathrm{Kd}$ values are in agreement with those estimated by $\mathrm{P} 2 /(\mathrm{P} 1 \times$ 100).
To save calculation time, the definition of $v$ was changed from the previous definition [14]. Under the present definition, random movements were simulated (Figure 1-III and 1-IV). The diffusion coefficient (D) was calculated as follows:

$$
\mathrm{D}=\left[\text { average value of }\{\mathrm{x}(0)-\mathrm{x}(\mathrm{t})\}^{2}+\{\mathrm{y}(0)-\mathrm{y}(\mathrm{t})\}^{2}\right] / 4 \mathrm{t}
$$

for the receptor, and

$$
\begin{gathered}
D=\text { [average value of }\{x(0)-x(t)\}^{2}+\{y(0)-y(t)\}^{2}+\{z(0)- \\
\left.z(t)\}^{2}\right] / 6 t
\end{gathered}
$$

for cytosolic proteins, where $\mathrm{x}(0), \mathrm{y}(0), \mathrm{z}(0), \mathrm{x}(\mathrm{t}), \mathrm{y}(\mathrm{t})$, and $\mathrm{z}(\mathrm{t})$ are their positions in the $\mathrm{x}, \mathrm{y}$, and $\mathrm{z}$ directions at 0 and $t$ seconds. The mean value for 1000 molecules was calculated. The cytosolic space and the cell surface contained $1200 \times 1200 \times 1200$ and $1200 \times 1200 \times 1$ subspaces, respectively. The average values were obtained from 4 sets of calculations, which took between 0.03 and 0.06 seconds. The diffusion coefficients of the cytosolic protein and the receptor were $10.8 \pm 0.3$ and $0.163 \pm$ $0.008(\mu \mathrm{m})^{2} \cdot$ second $^{-1}$, respectively. These values reflect experimental data for membrane and cytosolic proteins previously reported in prokaryotes [17] and eukaryotes $[18,19]$. These data suggested that our simulation procedure is adequate to achieve our purpose. We assumed that the diffusion rate of the ligand is close to that of cytosolic molecules because the extracellular space and cytosol both contain a large number of molecules including proteins.

\section{Ligand-receptor membrane complex formation}

It is generally accepted that receptors and associated membrane proteins such as adaptors and linkers are clustered in the micro-domains of the cell surface and that this clustering plays a role in intracellular signaling. Lipid rafts consisting of glycosphingolipids, cholesterol, and membrane proteins have been observed on the cell surface [20]. Other interactions of membrane proteins have been reported to involve the F-actin skeleton [21]. Previous

Table 2: Kd at equilibrium

\begin{tabular}{cccc}
\hline & \multicolumn{3}{c}{ Dissociation constant $(\mathrm{Kd})$} \\
\cline { 2 - 5 } & Theoretical $\left[\mathrm{P}_{2} /\left(\mathrm{P}_{1} \times 100\right)\right]$ & Simulated $(1)$ & Ratio $(2)$ \\
\hline $3.35 \times 10^{-4}$ & $5.00 \times 10^{-6}$ & $4.94 \times 10^{-6} \pm 0.33 \times 10^{-6}$ & 0.99 \\
$6.71 \times 10^{-5}$ & $1.00 \times 10^{-6}$ & $1.05 \times 10^{-6} \pm 0.06 \times 10^{-6}$ & 1.05 \\
$3.36 \times 10^{-5}$ & $5.02 \times 10^{-7}$ & $1.12 \times 10^{-7} \pm 0.36 \times 10^{-7}$ & 1.02 \\
$6.72 \times 10^{-6}$ & $1.00 \times 10^{-7}$ & Mean & 1.05 \\
\hline
\end{tabular}

(1)mean value and standard deviation of $\left(M_{A} \cdot M_{B}\right) / M_{A B}$ calculated from 5 simulations.

(2) simulated value/theoretical value. 
simulations by our group suggested that the clustering of membrane proteins such as receptors and adapters before ligand binding to receptors stimulated cell activation [14], in agreement with previous experimental data showing that receptors are associated with other membrane proteins in non-stimulated cells [22-25]. Therefore, we postulated that the membrane proteins associated with signal pathways cluster before ligand binding.

In the first simulation (model 1), the extracellular space and the cell surface consisted of $300 \times 300 \times 100$ and 300 $\times 300 \times 1$ subspaces, respectively. The numbers of $\mathrm{L}, \mathrm{R}$, and $\mathrm{A}$ at zero time were set as described in Figure 2. The setting of $\mathrm{L}$ to 180 corresponds to $200 \mathrm{nM}$. The setting of $\mathrm{R}$ and A to 86 corresponds to approximately $10,000 \mathrm{~mol}-$ ecules per cell, since the surface area of a spherical cell with a diameter of $10 \mu \mathrm{m}$ is $314 \mu \mathrm{m}^{2}$. More than $99 \%$ of $\mathrm{R}$ and A were clustered within $1.2 \times 10^{6}$ steps, and hence $\mathrm{L}$ was added immediately before the $1.2 \times 10^{6}$ th step. The concentration of extracellular ligands may not decrease with their binding to membrane receptors in situ because of the continuous supply of ligands from producing cells. To maintain a constant concentration of $\mathrm{L}$, one molecule of $\mathrm{L}$ was set at the opposite side when $\mathrm{L}$ was bound to $\mathrm{R}$ on the cell surface. When LR dissociated, L was deleted from the opposite boundary until extracellular $\mathrm{L}$ decreased to its original level. After the $1.5 \times 10^{7}$ th step $(\mathrm{t}$ $=3 \times 10^{2}$ seconds), $\mathrm{L}$ was allowed to pass through the borders of the simulation box, except for the cell surface and was deleted from the borders.

When dissociation constants of LR $\left(\mathrm{Kd}_{1}\right)$ and LRA $\left(\mathrm{Kd}_{2}\right)$ were equally set to $1 \times 10^{-7} \mathrm{M}$ or $1 \times 10^{-6} \mathrm{M}$, respectively, L was bound to $80 \%$ of the receptors $(8,000$ receptors per cell, Figure $2 \mathrm{~A}$ and $2 \mathrm{~B}$ ). Even when the ligand concentration decreased to 20 or $5 \mathrm{nM}$, L was bound to 8,000 and 4,000 receptors, respectively, although the rate of LRA formation was slow (Figure 2I to 2L). In contrast to complex formation, dissociation of the complex was very slow with these dissociation constants. When both $\mathrm{Kd}_{1}$ and $\mathrm{Kd}_{2}$ were $10^{-5} \mathrm{M}, \mathrm{L}$ was bound to approximately 6,000 receptors in the presence of $200 \mathrm{nM} \mathrm{L}$, and fast dissociation was shown (Figure 2C). Five thousand and 2,000 complexes were formed when the concentration of $\mathrm{L}$ was 20 and $5 \mathrm{nM}$, respectively (Figure $2 \mathrm{M}$ and $2 \mathrm{~N}$ ). When both $\mathrm{Kd}_{1}$ and $\mathrm{Kd}_{2}$ were $10^{-4} \mathrm{M}$, the complex level was 1,000 and 4,000 per cell in the presence of 200 and $2000 \mathrm{nM} \mathrm{L}$, respectively (Figure 2D and 2E). However, experimental studies showed that a ligand concentration of less than $100 \mathrm{nM}$ activated cells. When the cells contained a 5 fold excess of $\mathrm{R}$ and $\mathrm{A}(50,000$ per cell $), \mathrm{L}$ was bound to approximately 4,000 receptors even when the concentration of $\mathrm{L}$ was 20 $\mathrm{nM}$, and very rapid dissociation was demonstrated (Figure 2P).
These results suggest that the excess amount of receptors and its associate membrane proteins are not required for cell activation when the Kd is low or the concentration of $\mathrm{L}$ is high. However, it was shown that the prompt activation of the intracellular signal in the presence of a low amount of ligands and its rapid cessation after ligand clearance require an excess amount of receptors and membrane proteins. Cell activation with a low amount of ligands is favorable in situ.

When $\mathrm{Kd}_{1}$ and $\mathrm{Kd}_{2}$ were set to $10^{-6} \mathrm{M}$ and $10^{-4} \mathrm{M}$, respectively (Figure $2 \mathrm{~F}$ ), the simulation results were similar to that of Figure 2C. The product of the dissociation constant $\left(\mathrm{Kd}_{1} \times \mathrm{Kd}_{2}\right)$ was $10^{-10} \mathrm{M}$ in both cases. The same result was again obtained when $\mathrm{Kd}_{1}$ and $\mathrm{Kd}_{2}$ were set to $10^{-4} \mathrm{M}$ and $10^{-6} \mathrm{M}$, respectively (Figure $2 \mathrm{G}$ ).

The rate constants of LRA formation shown in Figure 2C $\left(\mathrm{Kd}_{1} \times \mathrm{Kd}_{2}=10^{-10} \mathrm{M}\right), \mathrm{M}\left(\mathrm{Kd}_{1} \times \mathrm{Kd}_{2}=10^{-10} \mathrm{M}\right)$, and $\mathrm{H}\left(\mathrm{Kd}_{1}\right.$ $\times \mathrm{Kd}_{2}=10^{-8} \mathrm{M}$ ) were calculated to be $2.7 \times 10^{5}, 3.2 \times 10^{5}$, and $1.4 \times 10^{5} \mathrm{M}^{-1} \cdot \mathrm{s}^{-1}$, respectively. These values are higher than those reported by Andrews, et al. [26], similar to rates observed in PMA (4 beta-Phorbol 12-myristate 13acetate) treated cells [27], and lower than values reported in other studies $[28,29]$.

\section{Negative feedback regulation of cytosolic signal pathways} In the simulation of cytosolic signal transduction, the signal pathway was assumed to be as described in the Methods section. When $\mathrm{Kd}_{1}$ and $\mathrm{Kd}_{2}$ were set at $10^{-5} \mathrm{M}$ and 10${ }^{4} \mathrm{M}$, respectively, ligands were bound to $40 \%$ of receptors in the presence of $200 \mathrm{nM} \mathrm{L}$, and rapid formation and dissociation of LRA were demonstrated (Figure $2 \mathrm{H}$ ). Therefore, we used these conditions for the signal transduction simulation. The concentrations of proteins and kinetic parameters were set as described in Additional file 1 and 2. All signal proteins (B to F) were activated rapidly after the ligand addition under conditions in which all signal proteins were activated at a high level (Figure 3-I, model $2 A)$. However, inactivation of $F$ was shown to be very slow under these conditions, even if the dissociation of the LRA complex was rapid (Figure 3-I, model 2A). As shown in Figure 3-I, when the levels of active $\mathrm{B}$ to $\mathrm{D}$ were low (Figure 3-I, model $2 \mathrm{~B})$, the activation rate of $\mathrm{F}\left(1.62 \times 10^{-9} \pm\right.$ $0.08 \mathrm{M} \mathrm{s}^{-1}, \mathrm{n}=3$ ) was slower than the rate in model $2 \mathrm{~A}$ $\left(1.89 \times 10^{-9} \pm 0.03 \mathrm{M} \mathrm{s}^{-1}, \mathrm{n}=3\right)$, but the inactivation of $\mathrm{F}$ was fast in model $2 \mathrm{~B}$.

Next, we postulated the following negative feedback regulatory mechanism (Figure 3-II) in which the amount of enzyme $\mathrm{IB}^{*}$, which inactivates $\mathrm{B}^{*}$, increased with the increase in $\mathrm{E}^{*}$ as follows:

$$
\mathrm{E}^{*}+\mathrm{I} \rightarrow \mathrm{E}^{*} \cdot \mathrm{I} \rightarrow \mathrm{E}^{*} \cdot \mathrm{I}_{\mathrm{B}}{ }^{*} \rightarrow \mathrm{E}^{*}+\mathrm{I}_{\mathrm{B}}{ }^{*},
$$




\begin{tabular}{|c|c|c|c|c|c|c|}
\hline $\begin{array}{c}\text { Number of } \\
\text { subspaces for L }\end{array}$ & $\begin{array}{c}300 \times 300 \\
\text { x100 }\end{array}$ & $\begin{array}{c}300 \times 300 \\
\text { xl0 }\end{array}$ & $\begin{array}{c}300 \times 300 \\
\text { xl000 }\end{array}$ & $\begin{array}{c}300 \times 300 \\
\text { x1000 }\end{array}$ & $\begin{array}{c}300 \times 300 \\
\text { xl000 }\end{array}$ & $\begin{array}{c}300 \times 300 \\
\text { x1000 }\end{array}$ \\
\hline L & 180 & 180 & 180 & 45 & 45 & 180 \\
\hline R & 86 & 86 & 86 & 86 & 258 & 430 \\
\hline A & 86 & 86 & 86 & 86 & 258 & 430 \\
\hline
\end{tabular}

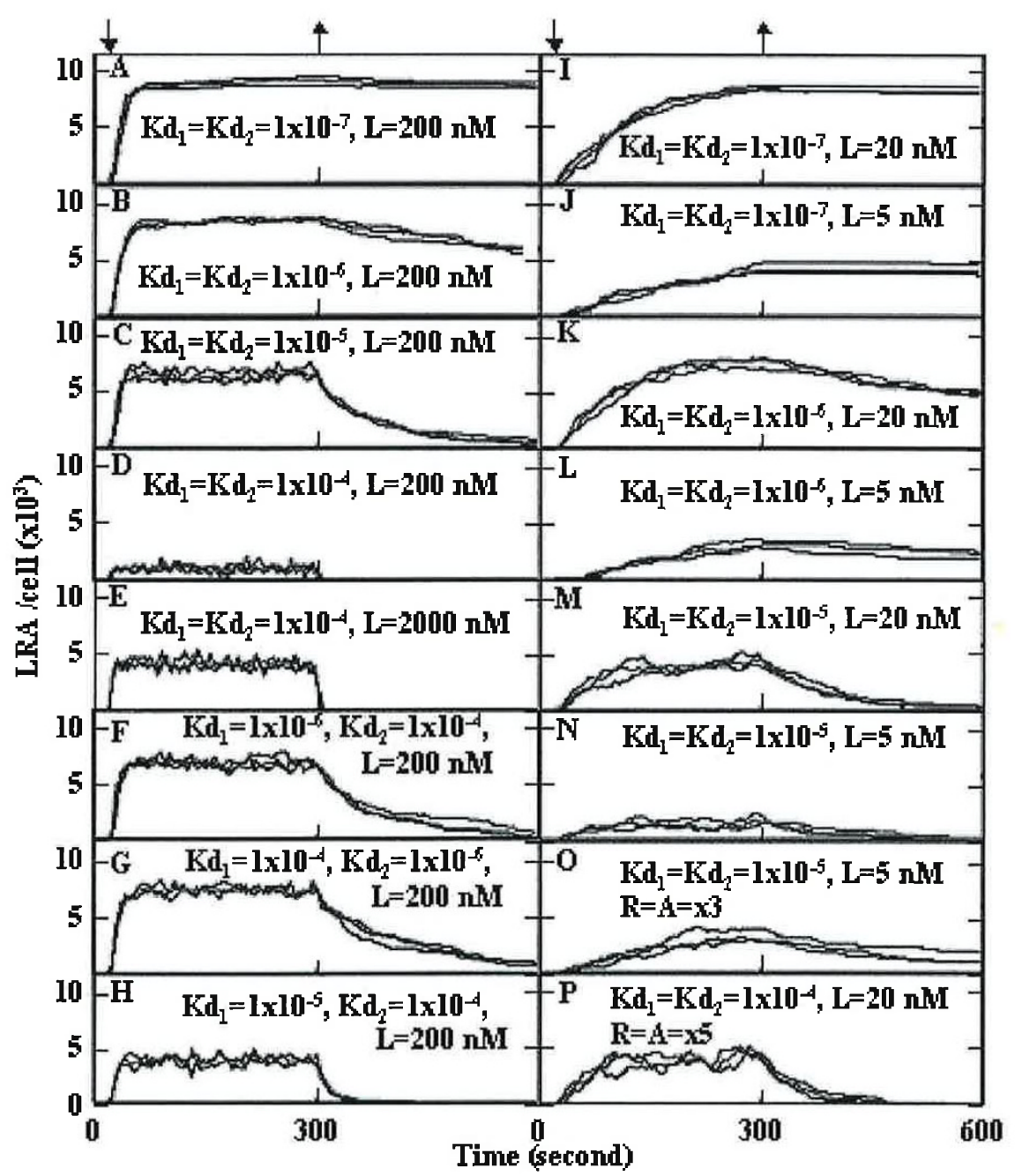

Figure 2

Simulation of LRA formation. The number of subspaces for $L$ and the number of molecules were set as shown in the upper Table. The dissociation constants of LR $\left(\mathrm{Kd}_{1}\right)$ and LRA $\left(\mathrm{Kd}_{2}\right)$ are indicated in the Figure. The probabilities of LR and LRA formations were set to 0.67 . $L$ was added immediately before the $1.2 \times 10^{6}$ th step (down arrow, 24 seconds). After the I.5 $\times$ $10^{7}$ th step (upper arrow, 300 seconds), $L$ was allowed to pass through the borders of the simulation box for $L$, except for the cell surface, and $L$ was deleted in the outside area. Three simulation results are represented. 


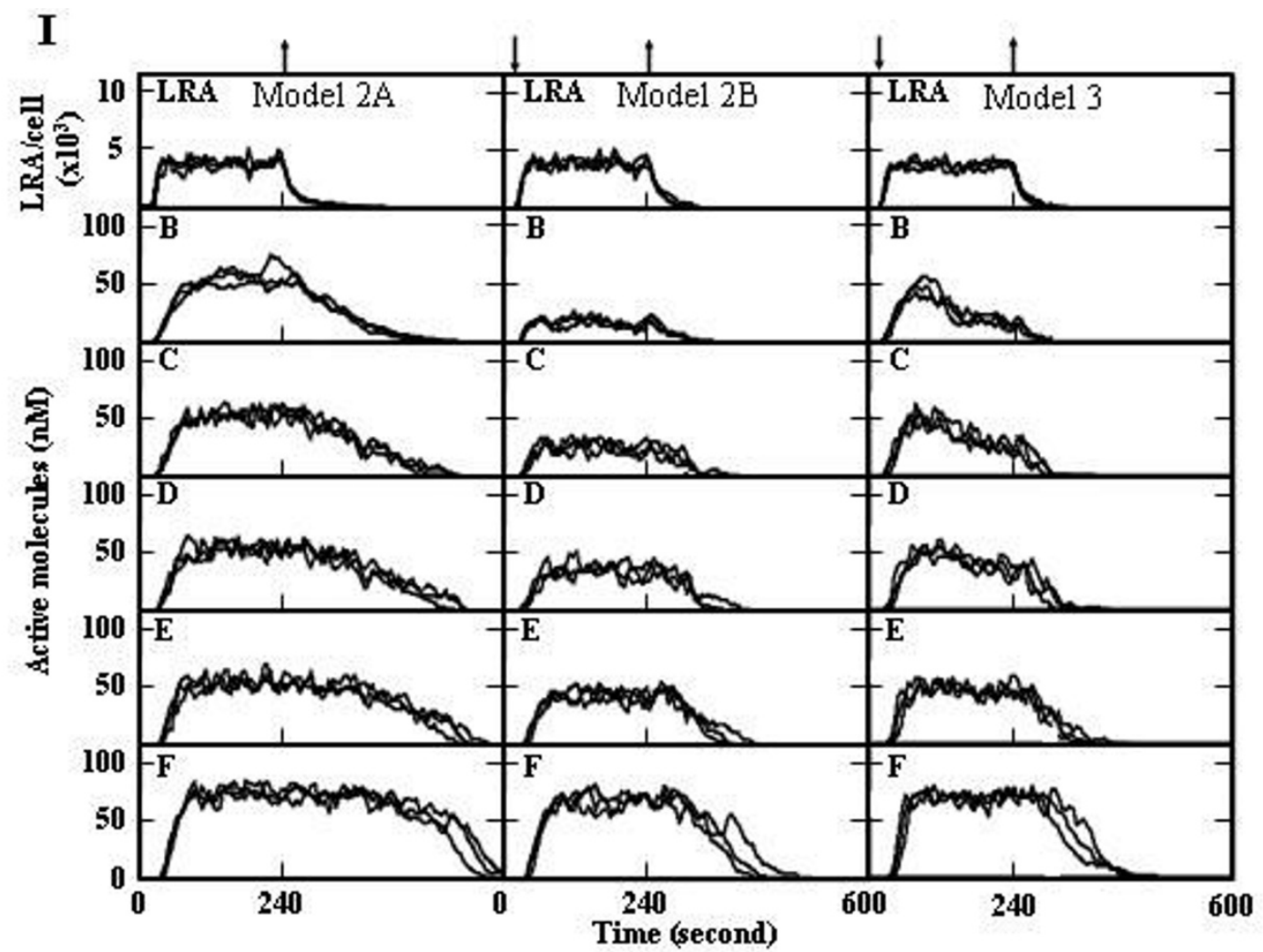

II

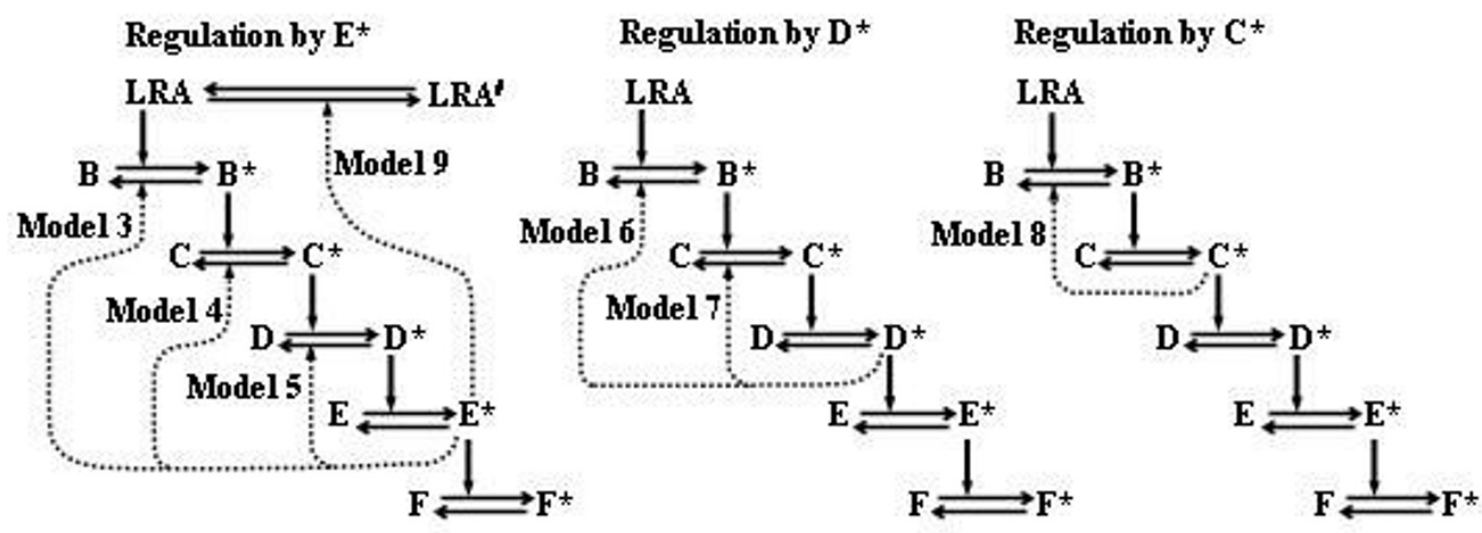

Figure 3

Negative feedback regulation of the signal pathways. I. The protein amounts and reaction probabilities were set as described in Additional file I and 2, respectively. $L$ was added immediately before the $1.2 \times 10^{6}$ th step (down arrow, 24 seconds) and removed after the $1.2 \times 10^{7}$ th step (upper allow, 240 seconds), as described in the legend of Figure 2 . Three simulation results are represented. II. Models for negative feedback regulation used in this study. 
where $I$ is the precursor of $\mathrm{I}_{\mathrm{B}}{ }^{*}$. Under this negative feedback regulation, the rapid activation of $\mathrm{F}\left(3.57 \times 10^{-9} \pm\right.$ $0.13 \mathrm{M} \mathrm{s}^{-1}, \mathrm{n}=3$ ) and prompt shutdown of active $\mathrm{F}$ were demonstrated (Figure 3-I, model 3). These simulation results led us to conclude that high levels of active intermediate signal proteins promote the activation of the final step of the signal pathway, and low levels of the active proteins are required for prompt signal shutdown.

\section{The mechanism in which the first signal protein is} regulated in a negative feedback manner is more effective Various models of negative feedback regulation were examined (Figure 3-II). When the level of $\mathrm{B}^{*}$ was regulated by $\mathrm{E}^{*}$, the rapid activation of $\mathrm{F}$ and inactivation of $\mathrm{F}^{*}$ were simulated (Figure 3 -I, model 3 ), as compared with regulatory systems in which the level of $\mathrm{C}^{*}$ (Figure 4, model 4) or $\mathrm{D}^{*}$ (Figure 4, model 5) was regulated by $\mathrm{E}^{*}$, namely $\mathrm{I}_{\mathrm{C}}{ }^{*}$ and $\mathrm{I}_{\mathrm{D}}{ }^{*}$ increased with increases in $\mathrm{E}^{*}$. $\mathrm{I}_{\mathrm{C}}{ }^{*}$ and $\mathrm{I}_{\mathrm{D}}{ }^{*}$ were produced from $\mathrm{I}$, as described above. Rapid shutdown was obtained when the level of $\mathrm{B}^{*}$ was regulated by $\mathrm{D}^{*}$ (Figure 4 , model 6 ) or $\mathrm{C}^{*}$ (Figure 4 , model 8 ), as compared with model 7 (the level of $\mathrm{C}^{*}$ was regulated by $\mathrm{D}^{*}$ ). These results suggest that negative feedback regulation of the $\mathrm{B}^{*}$ level is the most effective for the prompt activation and cessation of signal pathways, but the regulation of $\mathrm{B}^{*}$ by different molecules ( $\mathrm{C}^{*}$ to $\left.\mathrm{E}^{*}\right)$ had a similar effect on signal transduction.

It was shown that the membrane receptor complex was inactivated by the cytosolic signal protein in a negative feedback manner [30]. The final simulation was carried out under conditions in which LRA was inactivated by an increase in the level of $\mathrm{E}^{*}$ (model 9) as follows:

$\mathrm{E}^{*}+\mathrm{LRA} \underset{\mathrm{P} 12}{\stackrel{\mathrm{P} 11}{\rightleftarrows}} \mathrm{E}^{*} \cdot \mathrm{LRA} \underset{\mathrm{P} 14}{\stackrel{\mathrm{P} 13}{\rightleftarrows}} \mathrm{E}^{*} \cdot \mathrm{LRA}^{\#} \stackrel{\mathrm{P} 15}{\longrightarrow} \mathrm{E}^{*}+\mathrm{LRA}^{\#}$,

where LRA $^{\#}$ is unable to activate B. P11, P12, P13, P14, and P15 were set to $0.0200,2.00 \times 10^{-6}, 1.99 \times 10^{-4}, 3.35$ $\times 10^{-7}$, and 0.670 , respectively. The results showed that the shutdown speed in model 9 was close to the speed in model 3.

\section{Discussion}

The present simulation provided a kinetic explanation for why cells have a higher amount of receptors than is required to initiate signal transduction. When the dissociation constant is low, excess receptors are not required for cell activation, but signal shutdown is delayed after clearance of the ligand from the extracellular space. Even when the dissociation constant $\left(\mathrm{Kd}_{1} \times \mathrm{Kd}_{2}\right)$ was $10^{-8} \mathrm{M}$, the excess receptor was not required in the presence of $2 \mu \mathrm{M}$ extracellular ligand, but such a high concentration of ligand may not represent physiological conditions. There- fore, an excess amount of receptors is useful for the rapid activation and inactivation of intracellular signal transduction when ligand concentrations are at a physiological level.

Our simulation results can be applicable to other models. For example, when ligand-receptor complexes without other membrane proteins initiate cellular signaling, the dissociation constant of LR more than $10^{-9} \mathrm{M}$ was essential for rapid signal cessation and an excess amount of receptors was required for activation at a ligand level below $1 \mu \mathrm{M}$ (data not shown). If receptors are crosslinked by multivalent ligands, the following reactions are used

$$
\begin{gathered}
\mathrm{L}+\mathrm{R} \leftrightarrow \mathrm{LR} \text { and } \mathrm{LR}+\mathrm{R} \leftrightarrow \mathrm{LRR} \text { instead of } \mathrm{L}+\mathrm{R} \leftrightarrow \mathrm{LR} \text { and } \\
\mathrm{LR}+\mathrm{A} \leftrightarrow \text { LRA. }
\end{gathered}
$$

Therefore, similar results could be obtained because both have kinetic similarity. The signal transduction that is deactivated by the binding of other membrane components to ligand-receptor complexes shows similar kinetics to the model 9 using the component instead of $\mathrm{E}^{*}$ without P15.

Previous examinations of signal transfer pathways with the aid of computer simulations theoretically supported the negative feedback control of signal transfer observed experimentally [8-10], but its physiological meaning remained unclear. The present results clearly demonstrate that negative feedback regulation is required to promote the termination of a signal transfer system. The present simulation also suggests that negative feedback regulation of the first cytosolic signal protein is the most effective pathway. Experimental results have shown that the early steps of signal pathways are regulated in a negative feedback manner in many cases [31-36]. Other experimental studies revealed that the activation levels of signal proteins at the steady-state stage are very low [2-7], leading us to debate the physiological significance of such a low level of activation. The present simulation results have shown that a low activation level of signal proteins at the steadystate stage is of physiological importance for cellular signaling.

It has been proposed that negative feedback regulation represses fluctuations in signal transduction [10]. However, our present data revealed that the activation of signal proteins was not significantly stabilized by negative feedback regulation under our conditions (Figure 3 and 4 ).

Most computer simulations of biological phenomena have been performed with supercomputers using Unix based operating systems. This may be the reason why Monte Carlo techniques are still largely unavailable to most researchers. In contrast, our simulations were carried 


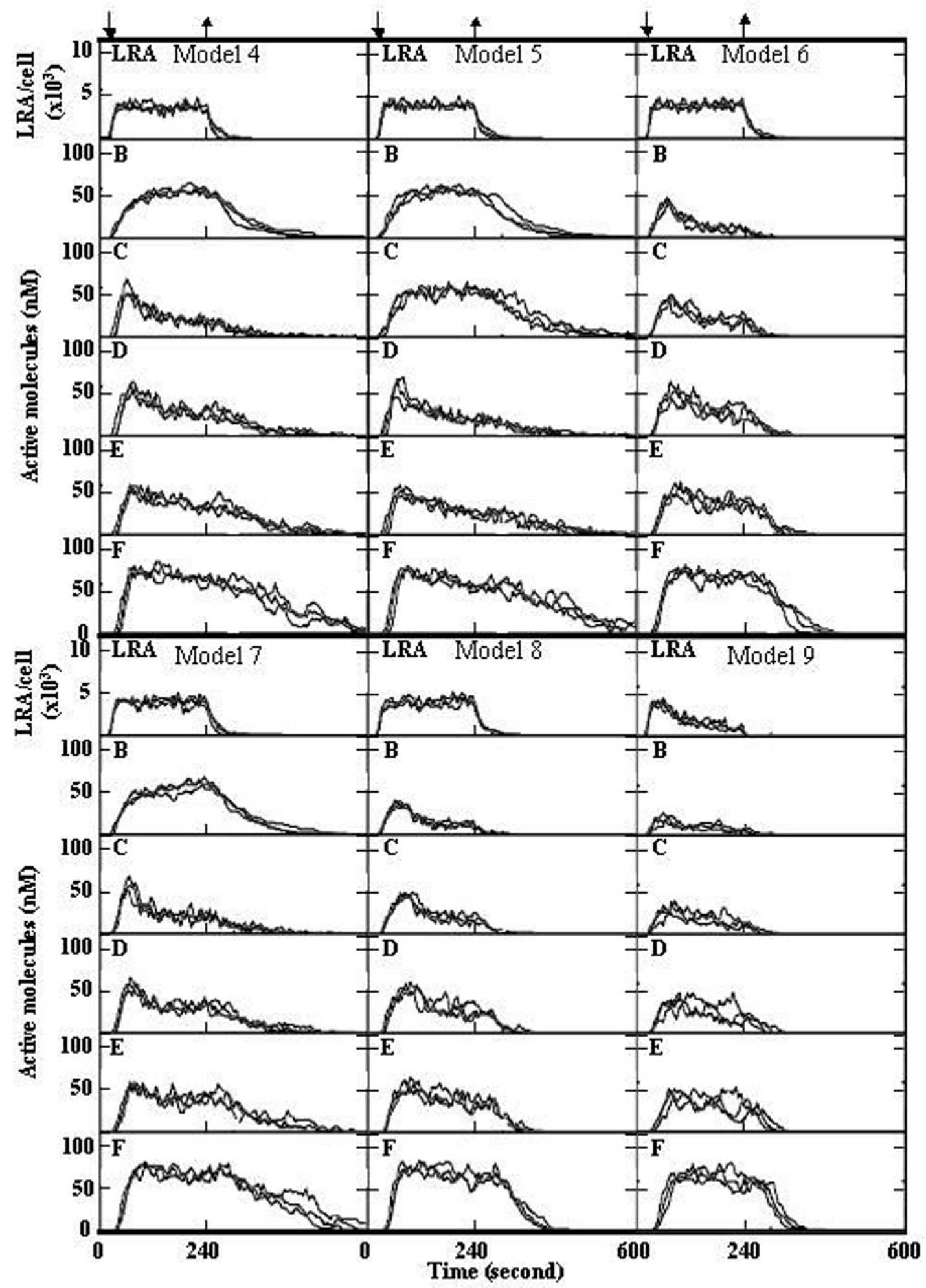

Figure 4

Simulations of various types of negative feedback regulation. The simulations were carried out as described in the legend of Figure 3. For detailed models, see the text. Three simulation results are represented. 
out on a conventional personal computer using the Windows XP or 2000 operating systems. The simulated values of diffusion coefficients and kinetic parameters were consistent with experimental data from literatures, demonstrating that our Monte Carlo simulation procedure is useful for kinetic analysis of cellular signal transduction. Furthermore, our simulation program can be used by other investigators for kinetic analysis of other biological phenomena with minor modifications, and neither special computing hardware nor special training is required.

\section{Conclusion}

The present kinetic analysis revealed that excess receptors and negative feedback regulation promote activation and cessation of signal transduction when ligand concentrations are at a low physiological level.

\section{Competing interests}

The authors declare that they have no competing interests.

\section{Authors' contributions}

HK carried out the simulation and wrote the manuscript. RA and TY participated in the design of simulation program and preparation of the manuscript.

\section{Additional material}

\section{Additional file 1}

Protein amounts. Amounts of proteins used for simulation.

Click here for file

[http://www.biomedcentral.com/content/supplementary/1478-

811X-7-3-S1.doc]

\section{Additional file 2}

Reaction probabilities. Reaction probabilities of each steps used for simulation.

Click here for file

[http://www.biomedcentral.com/content/supplementary/1478811X-7-3-S2.doc]

\section{References}

I. Uyemura T, Takagi H, Yanagida T, Sako Y: Single-molecule analysis of epidermal growth factor signaling that leads to ultrasensitive calcium response. Biophys J 2005, 88:3720-3730.

2. Muroya K, Hattori S, Nakamura S: Nerve growth factor induces rapid accumulation of the GTP-bound form of $\mathrm{p} 2 \mathrm{I}$ ras in rat pheochromocytoma PCI 2 cells. Oncogene 1992, 7:277-28I.

3. Traverse S, Seedorf K, Paterson H, Marshall CJ, Cohen P, Ullrich A: EGF triggers neuronal differentiation of $\mathrm{PCI} 2$ cells that overexpress the EGF receptor. Curr Biol I994, 4:694-70 I.

4. Alessi DR, Gomez N, Moorhead G, Lewis T, Keyse SM, Cohen P: Inactivation of p42 MAP kinase by protein phosphatase 2A and a protein tyrosine phosphatase, but not CLI00, in various cell lines. Curr Biol 1995, 5:283-295.

5. Nguyen TT, Scimeca JC, Filloux C, Peraldi P, Carpentier JL, Van Obberghen $\mathrm{E}$ : Co-regulation of the mitogen-activated protein kinase, extracellular signal-regulated kinase $I$, and the 90 . kDa ribosomal S6 kinase in PCI 2 cells. Distinct effects of the neurotrophic factor, nerve growth factor, and the mitogenic factor, epidermal growth factor. I Biol Chem 1993, 268:9803-9810.

6. Brysha M, Zhang JG, Bertolino P, Corbin JE, Alexander WS, Nicola NA, Hilton DJ, Starr R: Suppressor of cytokine signaling-I attenuates the duration of interferon gamma signal transduction in vitro and in vivo. J Biol Chem 200I, 276:22086-22089.

7. Cherniack AD, Klarlund JK, Conway BR, Czech MP: Disassembly of Son-of-sevenless proteins from Grb2 during p2I ras desensitization by insulin. J Biol Chem 1995, 270: I485- |488.

8. Brightman FA, Fell DA: Differential feedback regulation of the MAPK cascade underlies the quantitative differences in EGF and NGF signalling in PCI 2 cells. FEBS Lett 2000, 482:169-174.

9. Yamada S, Shiono S, Joo A, Yoshimura A: Control mechanism of JAK/STAT signal transduction pathway. FEBS Lett 2003, 534: $190-196$

10. Kholodenko BN: Cell-signalling dynamics in time and space. Nat Rev Mol Cell Biol 2006, 7:165-176.

II. Woolf PJ, Linderman J]: Self organization of membrane proteins via dimerization. Biophys Chem 2003, 104:217-227.

12. Nudelman G, London Y: Cell surface dynamics: the balance between diffusion, aggregation and endocytosis. IEE Proc-Syst Biol 2006, I 53:34-42.

13. Brinkerhoff C], Woold PJ, Linderman J]: Monte Carlo simulations of receptor dynamics: insights into cell signaling. J Mol Hiosol 2004, 35:667-677.

14. Kobayashi H, Azuma R, Konagaya A: Clustering of membrane proteins in the pre-stimulation stage is required for signal transduction: a computer analysis. Signal transduction 2007 7:329-339.

15. Matsumoto M, Nishimura T: Mersenne twister: A 623-dimensionally equidistributed uniform pseudo-random number generator. ACM Transactions on Modeling and Computer Simulation 1998, 8:3-30.

16. Azuma R, Kitagawa T, Kobayashi H, Konagaya A: Particle simulation approach for subcellular dynamics and interactions of biological molecules. BMC Bioinformatics 2006, 7(Suppl 4):S20.

17. Mullineaux CW, Nenninger A, Ray N, Robinson C: Diffusion of green fluorescent protein in three cell environments in Escherichia coli. J Bacteriol 2006, I 88:3442-3448.

18. Ishihara $A$, Hou $Y$, Jacobson $K$ : The Thy-I antigen exhibits rapid lateral diffusion in the plasma membrane of rodent lymphoid cells and fibroblasts. Proc Natl Acad Sci USA 1987, 84:1290-1293.

19. Zhang F, Crise B, Su B, Hou Y, Rose JK, Bothwell A, Jacobson K: Lateral diffusion of membrane-spanning and glycosylphosphatidylinositol-linked proteins: toward establishing rules governing the lateral mobility of membrane proteins. J Cell Biol 1991, I I 5:75-84.

20. Horejsi V: The roles of membrane micro-domains (rafts) in $\mathbf{T}$ cell activation. Immunol Rev 2003, I91:148-164.

21. Luna EJ, Hitt AL: Cytoskeleton-plasma membrane interactions. Science 1992, 258:955-964.

22. Varma R, Mayor S: GPI-anchored proteins are organized in submicron domains at the cell surface. Nature 1998, 394:798-80I.

23. Zacharias DA, Violin JD, Newton AC, Tsien RY: Partitioning of lipid-modified monomeric GFPs into membrane microdomains of live cells. Science 2002, 296:913-916.

24. Sharma P, Varma R, Sarasij RC, Ira , Gousset K, Krishnamoorthy G, Rao M, Mayor S: Nanoscale organization of multiple GPIanchored proteins in living cell membranes. Cell 2004, I 16:577-589.

25. Leksa V, Godar S, Schiller HB, Fuertbauer E, Muhammad A, Slezakova K, Horejsi V, Steinlein P, Weidle UH, Binder BR, Stockinger H: TGFbeta-induced apoptosis in endothelial cells mediated by M6P/IGFII-R and mini-plasminogen. J Cell Sci 2005, I I 8:4577-4586.

26. Andrews AL, Holloway JW, Puddicombe SM, Holgate ST, Davies DE: Kinetic analysis of the interleukin- 13 receptor complex. J Biol Chem 2002, 277:46073-46078.

27. Felder S, LaVin J, Ullrich A, Schlessinger J: Kinetics of binding endocytosis, and recycling of EGF receptor mutants. J Cell Biol 1992, I 1 7:203-212.

28. Wilkinson JC, Stein RA, Guyer CA, Beechem JM, Staros JV: Realtime kinetics of ligand/cell surface receptor interactions in living cells: binding of epidermal growth factor to the epidermal growth factor receptor. Biochemistry 200I, 40:10230-10242. 
29. Teramura Y, Ichinose J, Takagi H, Nishida K, Yanagida T, Sako Y: Single-molecule analysis of epidermal growth factor binding on the surface of living cells. EMBO J 2006, 25:42I5-4222.

30. Reth M, Brummer T: Feedback regulation of lymphocyte signalling. Nat Rev Immunol 2004, 4:269-277.

31. Jove R: Preface: STAT signaling. Oncogene 2000, 19:2466-2467.

32. Kerr IM, Costa-Pereira AP, Lillemeier BF, Strobl B: Of JAKs, STATs, blind watchmakers, jeeps and trains. FEBS Lett 2003, 546: $1-5$.

33. Heinrich PC, Behrmann I, Müller-Newen G, Schaper F, Graeve L: Interleukin-6-type cytokine signalling through the gp I30/Jak/ STAT pathway. Biochem J 1998, 334:297-3|4.

34. Langlois WJ, Sasaoka T, Saltiel AR, Olefsky JM: Negative Feedback Regulation and Desensitization of Insulin and Epidermal Growth Factor stimulated p2 I ras Activation. J Biol Chem I995, 270:25320-25323.

35. Brummer T, Naegele $H$, Reth M, Misawa $Y$ : Identification of novel ERK-mediated feedback phosphorylation sites at the C-terminus of B-Raf. Oncogene 2003, 22:8823-8834.

36. Dhillon AS, von Kriegsheim A, Grindlay J, Kolch W: Phosphatase and feedback regulation of Raf-I signaling. Cell Cycle 2007, 6:3-7.

Publish with Bio Med Central and every scientist can read your work free of charge

"BioMed Central will be the most significant development for disseminating the results of biomedical research in our lifetime. "

Sir Paul Nurse, Cancer Research UK

Your research papers will be:

- available free of charge to the entire biomedical community

- peer reviewed and published immediately upon acceptance

- cited in PubMed and archived on PubMed Central

- yours - you keep the copyright 